\title{
Adaptation of activated sludge with anammox to low temperatures
}

\author{
Igor Gulshin ${ }^{1, *}$, and Nikolay Makisha ${ }^{1}$ \\ ${ }^{1}$ Moscow State University of Civil Engineering, Department of Water Supply and Sanitation, 26 \\ Yaroslavskoye shosse, 129337 Moscow, Russia
}

\begin{abstract}
The article presents the results of evaluating the ability of activated sludge, saturated with anammox bacteria, to adapt to mesophilic and lower temperature operating conditions. As the main temperature regimes, temperatures of $30,25,15$, and $13^{\circ} \mathrm{C}$ were selected. The system has demonstrated stable operation at temperatures about $15^{\circ} \mathrm{C}$ with the highest degree of purification for ammonium nitrogen $-0.33 \mathrm{mg} / \mathrm{L}$. At the same time, the concentration of nitrites reached $0.07 \mathrm{mg} / \mathrm{L}$ taking into account forced nitration. An additional increase in the efficiency of the system requires structural changes in the adopted technological scheme of the bioreactor, however, the introduction of an internal system of recirculation of attached biomass (with load) inside the anammox compartment is considered as an essential element of the system that ensures stability.
\end{abstract}

\section{Introduction}

The possibility of using energy-efficient processes in wastewater treatment remains one of the significant tasks along with improving the quality of treatment quality [1]. There are many ways to reduce the energy costs of biological wastewater treatment processes, however, when considering them, one should not forget about the serious limiting condition - the stability of the quality of wastewater treatment when changing the operating conditions of the biological system $[2,3]$.

In the case of domestic wastewater treatment, the main indicators determining the quality of treatment, in most cases, are the integrated indicators of organic pollution (BOD, COD), nutrients (nitrogen and phosphorus) and suspended solids. In addition, while standard complete biological treatment in the first half of the twentieth century could provide highquality removal of organic contaminants and suspended solids, modern requirements for the almost complete removal of nutrients make it necessary to develop and use complex biological systems with a much higher risk of loss of stability during operation.

In the last 15 years, anammox processes have been studied as one of the most promising technologies for biological wastewater treatment [4, 5]. Anammox - anaerobic (anoxic) oxidation of ammonia, realized by Planctomycetes, in which nitrite acts as an electron acceptor. Various technology variations based on the anammox process have been introduced at two or three dozen facilities around the world, but in the vast majority of cases, they are

\footnotetext{
* Corresponding author: GulshinIA@mgsu.ru
} 
used to treat the side stream formed after treatment excess activated sludge $[6,7]$. This is mainly due to the requirements for the quality of purified water (the ratio of ammonia nitrogen, nitrites and other components), as well as to the temperature regime of treatment. The most favourable temperatures for the anammox process correspond to the mesophilic regime of $25-40^{\circ} \mathrm{C}$. Return wastewater discharg ed from the digester usually has an elevated temperature relative to the main wastewater stream, which allows efficient incorporating anammox reactors into the wastewater treatment scheme.

Despite the increased effectiveness of the application of anammox processes for the treatment of precisely return effluents with extremely high nitrogen concentrations, studies are being carried out on the introduction of these technologies for the treatment and the main stream of domestic wastewater entering the station. As noted above, the main problem with this is the rather low average temperature of the incoming wastewater, which directly affects the speed of the processes.

As part of a comprehensive study aimed at developing an effective technology for treating urban wastewater using a low oxygen anammox process, the ability to adapt activated sludge saturated with anammox to work under low oxygen conditions was studied.

\section{Materials and methods}

The study was carried out based on a laboratory bioreactor with an upward flow of sludge mixture, which is shown in Figure 1. The bioreactor implements a technological scheme with incomplete nitrification (nitration) and subsequent anammox reaction.

Using a metering pump (1), the model fluid enters the free aeration zone (3), which also receives compressed air through the duct (11) from the blower (2). Nitration occurs in free volume at dissolved oxygen concentrations of $0.5-0.7 \mathrm{mg} / \mathrm{L}$ for 1.5 hours, after which water enters anammox through a porous material that has closed (4) and open (5) areas (6). There is attached (8) and floating loading (9). In this section, dissolved oxygen can only be in the composition of the incoming sludge mixture, no additional aeration is performed. Inside the anammox compartment, internal recirculation of the sludge mixture and floating load is supported by means of agitators (7) to prevent the occurrence and development of decay of organic contaminants. The hydraulic retention time in this compartment is 4 hours. After the anammox separation, the free-floating sludge mixture (the floating load with the anammox does not go beyond the anammox separation) enters the free aeration zone (10) for deep purification of water from organic contaminants and possible residues of nitrites / ammonium nitrogen without exceeding the permissible nitrate concentrations in the treated effluent water. The treated wastewater (12) enters the secondary settler (13) with a variable volume for the deposition of activated sludge. Precipitated activated sludge (15) is fed into aerated compartments, and treated wastewater (14) is removed from the installation.

As the incoming wastewater (substrate), a model fluid with the characteristics indicated in Table 1 was used.

Table 1. Model fluid concentrations.

\begin{tabular}{|c|c|c|}
\hline Parameter & Value & Measurement \\
\hline$\left[\mathrm{N}-\mathrm{NH}_{4}{ }^{+}\right]$ & $35 \pm 5$ & $\mathrm{gN} / \mathrm{m}^{3}$ \\
\hline$\left[\mathrm{N}^{3} \mathrm{NO}_{2}{ }^{-}\right]$ & $0.5 \pm 0.5$ & $\mathrm{gN} / \mathrm{m}^{3}$ \\
\hline$\left[\mathrm{N}^{3} \mathrm{NO}_{3}{ }^{-}\right]$ & $0.5 \pm 0.5$ & $\mathrm{gN} / \mathrm{m}^{3}$ \\
\hline
\end{tabular}




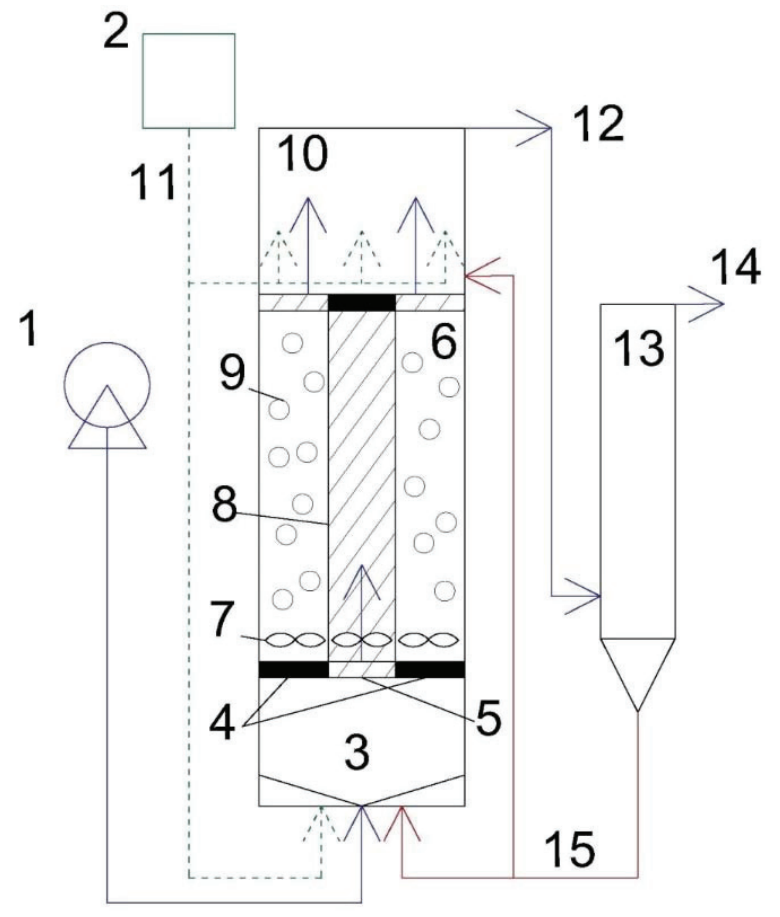

Fig. 1. Scheme of the laboratory bioreactor.

During the nitrification process, the composition of the liquid changed; the concentrations of ammonium nitrogen and nitrites at the entrance to the anammox compartment should have been at the levels of 15 and $19 \mathrm{mg} / \mathrm{L}$, respectively. If this did not happen and nitrite was not enough, then a solution of sodium nitrite was added. In the general case, the ratio of ammonium nitrogen and nitrites at the entrance to the anammox compartment was maintained at 1.23 .

For quantitative chemical analyzes, sampling was carried out from specially designated control points of the plants, as well as from a tank with a working model fluid and from a discharge tray. The list of regularly performed analyzes included the following indicators: $\mathrm{COD}, \mathrm{BOD}_{5}, \mathrm{TSS}, \mathrm{P}-\mathrm{PO}_{4}, \mathrm{~N}-\mathrm{NO}_{3}, \mathrm{~N}-\mathrm{NO}_{2}, \mathrm{~N}-\mathrm{NH}_{4}, \mathrm{pH}, \mathrm{SO}_{4}, \mathrm{Cl}, \mathrm{TN}$. Respirometric experiments were performed using the OxiTop Control 12 automated system. All the measuring instruments used were metrologically provided throughout the study. The testing equipment necessary for the analysis was certified.

The concentration of dissolved oxygen was measured online using an electrode, and its concentration in the sludge mixture at the entrance to the anammox compartment was always $0.1 \mathrm{mg} / \mathrm{L}$. The temperature was measured and maintained using a cooling system and an electric heater. The cooling system consisted of a pipe braided around a reactor column with a recirculating liquid with a temperature of about $-3^{\circ} \mathrm{C}$. Three different operating temperatures were investigated: $25^{\circ} \mathrm{C}, 15^{\circ} \mathrm{C}$ and $13^{\circ} \mathrm{C}$. The rate of liquid rise $\left(\mathrm{V}_{\mathrm{c}}\right)$ in the free compartments was in the range from 0.3 to $1.0 \mathrm{~m} / \mathrm{h}$ with an average value of $0.7 \pm 0.2 \mathrm{~m} / \mathrm{h}$ to guarantee stable granule diameters. The flow rate of the sludge mixture depended on the flow rate of the incoming wastewater.

Active sludge for the study was selected from the existing experimental installation located at the Lyubertsy treatment facilities. According to preliminary analysis, the degree of saturation with anammox culture was about $35 \%$. 


\section{Results and discussion}

The experiment was divided into four stages, depending on the temperature of the working medium in the reactor.

The first stage was carried out at a temperature characteristic of anammox $-30^{\circ} \mathrm{C}$, at which activated sludge was adapted to the new technological regime of the reactor itself. This stage took 15 days. Then within 60 days 3 more stages were implemented ( 20 days for each stage) - a gradual decrease in temperature $-25,15$ and $13^{\circ} \mathrm{C}$. The concentration of total mineral nitrogen $\left(\mathrm{N}-\mathrm{NH}_{4}+\mathrm{N}-\mathrm{NO}_{2}+\mathrm{N}-\mathrm{NO}_{3}\right)$ relative to the load on activated sludge with nitrogen was used as the main evaluation criterion. Due to the average duration of the experiment (less than 100 days), the percentage of anammox bacteria in the sludge was assumed constant, which was additionally confirmed by analysis at the end of the experiment. The results of the analyses are presented in Table 2.

Table 2. Results of the experiment.

\begin{tabular}{|c|c|c|c|c|c|}
\hline $\begin{array}{c}\text { Day of the } \\
\text { experiment }\end{array}$ & $\begin{array}{c}\text { Temperature, } \\
{ }^{\circ} \mathrm{C} \\
\end{array}$ & $\begin{array}{c}\text { Load } \\
{[\mathrm{mgN} / \mathrm{gVSS}]}\end{array}$ & $\begin{array}{l}\mathrm{N}_{-\mathrm{NH}_{4}}^{+} \\
{[\mathrm{mg} / \mathrm{L}]}\end{array}$ & $\begin{array}{l}\mathrm{N}^{-\mathrm{NO}_{2}^{-}} \\
{[\mathrm{mg} / \mathrm{L}]}\end{array}$ & $\begin{array}{l}\mathrm{N}^{-\mathrm{NO}_{3}}{ }^{-} \\
{[\mathrm{mg} / \mathrm{L}]}\end{array}$ \\
\hline 0 & \multirow{4}{*}{30} & 19.44 & 2.11 & 0.9 & 15.0 \\
\hline 5 & & 22.50 & 2.05 & 1.2 & 17.1 \\
\hline 10 & & 19.47 & 1.91 & 0.3 & 12.0 \\
\hline 15 & & 18.10 & 0.75 & 0.1 & 8.4 \\
\hline 20 & \multirow{5}{*}{25} & 21.05 & 0.51 & 0.1 & 8.5 \\
\hline 25 & & 22.78 & 0.33 & 0.07 & 6.6 \\
\hline 30 & & 19.44 & 0.41 & 0.08 & 7.9 \\
\hline 35 & & 18.95 & 0.38 & 0.1 & 9.0 \\
\hline 40 & & 17.14 & 0.51 & 0.15 & 10.1 \\
\hline 45 & \multirow{4}{*}{15} & 18.50 & 0.37 & 0.12 & 11.2 \\
\hline 50 & & 18.10 & 0.52 & 0.09 & 10.5 \\
\hline 55 & & 21.05 & 0.61 & 0.08 & 11.3 \\
\hline 60 & & 21.58 & 0.63 & 0.08 & 11.2 \\
\hline 65 & \multirow{4}{*}{13} & 22.78 & 1.55 & 0.22 & 15.6 \\
\hline 70 & & 20.11 & 1.82 & 0.35 & 16.7 \\
\hline 75 & & 20.59 & 2.14 & 0.45 & 18.8 \\
\hline 80 & & 21.67 & 2.15 & 0.40 & 19.1 \\
\hline
\end{tabular}

According to the results of adaptation, it is clear that at equal loads, activated sludge adapted to the system at medium-low temperatures. Anammox bacteria maintained stable performance in the attached state. The work of AOB (nitrifying) bacteria was maintained in a stable state with ensuring deep post-treatment in the last contact zone of the bioreactor. At temperatures less than $15^{\circ} \mathrm{C}$, the efficiency of the system was significantly reduced. The indicators of purified water, even taking into account deep post-treatment in the contact zone, require additional adjustment.

\section{Conclusion}

Low-oxygen technologies for urban wastewater treatment are a promising solution, but require a careful assessment of stability for each specific case [8-10]. A study of the operation 
of anammox processes under the conditions of a developed technological scheme has demonstrated stable efficiency at temperatures about $15^{\circ} \mathrm{C}$. For the system to operate at lower temperatures, typical for some regions of Russia, it is necessary to make constructive changes to the technological mode, which will be taken into account at the next stage of the research.

\section{References}

1. S. A. Volkov, E. V. Makisha, Inž. vestn. Dona, 4 (2018)

2. C. Reino, M. E. Suárez-Ojeda, J. Perez, J. Carrera, Water Res., 128, 331-340 (2018)

3. C. Reino, J. Carrera, Chem. Eng. J., 313, 217-225 (2017)

4. M. Laureni, D. G. Weissbrodt, I. Szivák, O. Robin, J. L. Nielsen, E. Morgenroth, A. Joss, Water Res., 80, 325-336 (2015)

5. R.Żyłka, W.Dąbrowski, E. Gogina, O.Yancen, J. of Ecol. Eng., 19, 269-275 (2018)

6. E. M. Gilbert, S. Agrawal, S. M. Karst, H. Horn, P. H. Nielsen, S. Lackner, Environ. Sci. Technol., 48, 8784-8792 (2014)

7. T. L. G. Hendrickx, C. Kampman, G. Zeeman, H. Temmink, Z. Hu, B. Kartal, C. J. N. Buisman, Bioresour. Technol., 163, 214-221 (2014)

8. A. A. Van de Graaf, P. de Bruijn, L. A. Robertson, M. S. Jetten, J. G. Kuenen, Microbiology, 142, 2187-2196 (1996)

9. I. Gulshin, Matec Web of Conferences, 106 (EDP Sciences, 2017)

10. E. S. Gogina, I. A. Gulshin, WiST, 12 (2017) 